\title{
Jogpolitika
}

\author{
BORDÁs PÉTER*
}

\section{„Pénzetlen utas nem tud messze menni” - A helyi önkormányzatok költségvetési kiadásai 1993-2010 között, majd 2010 után $^{1}$}

\author{
forrásszabályozás - kiadási oldal - önkormányzati költségvetés - \\ helyi közfeladatok - centralizáció
}

\begin{abstract}
A forrásszabályozási rendszer bevételi struktúrájának ismerete önmagában nem alkalmas arra, hogy kellő és átfogó képet kaphassunk a helyi önkormányzatok közel húsz éven át müködő feladatellátási tapasztalatairól. A költségvetések bevételi oldala megmutatja számunkra, hogy milyen pénzügyi eszközök álltak rendelkezésre, miből gazdálkodhattak az önkormányzatok, de ehhez hozzá kell illeszteni azt a feladatkört, amelyet finanszírozni kellett. A bevételi struktúrát és annak hiányosságait egy korábbi tanulmányomban már bemutattam, ${ }^{2}$ így most azt kiegészítve a kiadási oldal részletes elemzésére törekszem. Már csak azért is, mert a kiadási szerkezet nagyban befolyásolja a helyi pénzügyi autonómia fokát is. A tanulmány célja, hogy 1993 és 2010 között bemutassa a helyi önkormányzatok közfeladat-ellátási körét, majd reagáljon a 2010 után tapasztalható változásokra, a helyi költségvetés kiadási szerkezetének alakulására. Teszi mindezt a célból, hogy megvizsgálhassuk azt a sokszor emlegetett kritikát, hogy a forrásszabályozási rendszer nem volt képes kellő fedezetet biztosítani a közfeladatok ellátására, ennek a hitelfelvétel és az eladóso-
\end{abstract}

* Bordás Péter PhD-hallgató, Debreceni Egyetem Állam- és Jogtudományi Kar Pénzügyi Jog és Közmenedzsment Tanszék; tudományos segédmunkatárs, MTA-DE közszolgáltatási kutatócsoport, bordaspeter. ajk@gmail.com.

1 A tanulmány a Magyar Tudományos Akadémia és a Debreceni Egyetem Állam- és Jogtudományi Kar közös, MTA-DE Közszolgáltatási Kutatócsoportjának a Területi közszolgáltatások szabályozásai című projektje keretében készült. A projekt leírására lásd HoRvÁtH M. Tamás: Szempontok a területi közszolgáltatások regulációs változásainak vizsgálatához. In: Horváth $\mathrm{M}$. Tamás (szerk.) Kilengések. Közszolgáltatási változások. Dialóg Campus, Budapest, 2013, 9-25.

2 BordÁs Péter: Határtalan hatások a pénzügyi decentralizációban. Miskolci Jogi Szemle, 2015/1, $129-147$. 
dás lett a következménye helyi szinten, mely végül az állami beavatkozás alapjául szolgálhatott. Kérdésként felvethetjük tehát: mi okozta a rendszer hiányosságait, a finanszírozási logika vagy a feladatelosztás defektusai? E kérdés megválaszolásához elöször a feladatrendszer és a jogszabályi környezet, majd a költségvetési kiadási adatok vizsgálata szükséges.

\section{Szerteágazó közfeladatok helyi szinten}

A rendszerváltás után kialakuló önkormányzati rendszer formailag ugyan kétszintủ volt, de a feladatellátásban valójában a települési önkormányzatok kerültek meghatározó szerepbe, a megyei szint súlya nem lett kardinális. ${ }^{3}$ Így a helyi közkiadások vizsgálata során elsődlegesen a települési szintet elemzem, de a megyei önkormányzatok és a kistérségi társulások is górcső alá kerülnek.

A helyi kiadások vizsgálata előtt - annak megértéséhez - érdemes áttekinteni, hogy a forrásszabályozási rendszerben hogyan is nézett ki az önkormányzatok feladatköre, milyen kötelező feladatokat állapított meg az önkormányzati törvény (a továbbiakban: Ötv. $)^{4}$ számukra. A rendszerváltás után kialakuló, és körülbelül 2011-ig müködő finanszírozási megoldást forrásszabályozásnak nevezi a szakirodalom, mely módszer alapvetően a helyi bevételek szabályozásában állt, s nem a kiadásokéban.

Jogszabályi szinten differenciált volt a feladattelepítés. Az Ötv. deklarálta, hogy a községnek, városnak, fövárosnak és kerületeinek, valamint a megyei önkormányzatnak egymástól eltérő feladat- és hatáskörei lehetnek. ${ }^{5} \mathrm{Ez}$ azt jelentette, hogy a nagyobb lakosságszámú és teljesítőképességü önkormányzatoknak több kötelező feladat- és hatáskört is megállapíthatott jogszabály. A kisebb lakosságszámú település önkormányzata müködési területén önként vállalhatta a törvény által a nagyobb lakosságszámú települési önkormányzatnak, illetve megyei önkormányzatnak kötelezően elöirt közszolgáltatás megszervezését. Bár már ekkor is lehetőség volt az átvállalt feladattal arányos költségvetési támogatás igénylésére, ez a gyakorlatban kevésbé érvényesült. A települések (főváros, megyei jogú város, város, község) között jogi státuszbeli különbséget nem tett a szabályozás, még akkor sem, ha körzeti jelleggel egyesek több feladatot láttak el. Az önkormányzati törvény azt is lefektette, hogy a megyei és a települési önkormányzatok között nincs függöségi viszony, feladataik ellátásának érdekében együttmüködnek.

A települési önkormányzati közfeladatok teljes körének meghatározásához a vizsgált időszakban az akkori Ötv. ad támpontot, ugyanis példálózó jelleggel felsorolta azokat. Ez alapján a települési önkormányzatok a lehetőségeikhez és a lakossági igényekhez igazodva az alábbi feladatok közül határozták meg, hogy mit, milyen módon látnak el, úgymint: a településfejlesztés, a településrendezés, az épített és természeti környezet védelme, a lakásgazdálkodás, a vízrendezés és a csapadékvíz-

3 ÁRVA Zsuzsanna-BALÁzs István-BALlA Zsuzsanna-BARTA Attila-VEszPrÉmı Bernadett: Helyi önkormányzatok. Debreceni Egyetemi Kiadó, Debrecen, 2012, 22.

4 1990. évi LXV. törvény, hatályos: 1990-töl 2011-ig.

5 Ötv. 6. $§(1)$ bekezdés. 
elvezetés, a csatornázás, a köztemető fenntartása, a helyi közutak és közterületek fenntartása, helyi tömegközlekedés, a településtisztaság biztosítása; gondoskodás a helyi tűzvédelemröl, helyi közbiztonság; közremüködés a helyi energiaszolgáltatásban, a foglalkoztatás megoldásában; az óvodáról, az alapfokú nevelésröl, oktatásról, az egészségügyi, a szociális ellátásról való gondoskodás; a közösségi tér biztosítása; közművelődési, tudományos, művészeti tevékenység, sport támogatása; a nemzeti és etnikai kisebbségek jogai érvényesítésének a biztosítása; az egészséges életmód közösségi feltételeinek elösegítése. ${ }^{6}$ Ezek közül a jogszabály kiemelést tett, és rögzítette, hogy a települési önkormányzat számára nemcsak lehetöség, hanem kötelesség gondoskodni bizonyos alapfokú közszolgáltatásokról, úgymint az egészséges ivóvízellátásról, az alapfokú oktatásról, az egészségügyi és a szociális alapellátásról, a közvilágításról, a helyi közutak és a köztemető fenntartásáról, a nemzeti és az etnikai kisebbségek jogainak érvényesüléséről. ${ }^{7} \mathrm{E}$ feladatok részletes szabályait, valamint a helyi feladatok meghatározását ágazati jogszabályok tartalmazták.

Meg kell említeni a feladatok egy másik nagy körét, melyek az államtól átvett hatósági feladatok voltak. A korábbi rendszer ezeket a hatósági és közszolgáltatási feladatokat igyekezett a helyi önkormányzatokhoz telepíteni, és azokat a helyi feladatellátás részének tekintette. Az ilyen feladatok száma a rendszer végére elérte, sőt meghaladta az ezret, ${ }^{8}$ ami különösen a hivatali apparátus müködtetésére volt kihatással.

Mindezt kiegészítette a települések teljesítőképességétöl függően, önként vállalt feladatok köre, mellyel kapcsolatban az Ötv. nyitva hagyta az önkormányzatok mozgásterét, mivel azt rögzítette, hogy a helyi önkormányzat önként vállalt, illetöleg kötelezöen elöírt feladat- és hatáskörei a helyi közügyek széles körét fogják át. ${ }^{9}$

A rendszerben alapvetően a humán jellegü helyi feladatok voltak többségben, amelyek azért is kiemelendőek, mivel a szolgáltatás színvonalát központi jogszabályban meghatározott paramétereknek megfelelően kellett biztosítani valamennyi településen. Ehhez kapcsolódik az a megállapítás is, hogy méretgazdaságossági okokból a kisebb településeken arányában drágább volt biztosítani ugyanazt a humán szolgáltatást, amit egy városban. ${ }^{10} \mathrm{~A}$ gazdasági feladatok, mint például a kommunális szolgáltatások, annyiban voltak speciálisak, hogy az önkormányzatoknak nagyobb mérlegelési körük volt a szolgáltatásszervezésben, így a költségvetési kiadásaik is változatosan alakultak.

A megyei önkormányzat esetében sem tartalmazott taxatív felsorolást a törvény, csak annyit mondott, hogy köteles ellátni azokat a törvényben elöírt feladatokat, amelyek megoldására települési önkormányzat nem kötelezhető. Továbbá, hogy törvény a megyei önkormányzat számára kötelezővé teheti az olyan körzeti jellegü közszolgáltatás biztosítását, amely a megye egész területére vagy nagy részére ki-

Ötv. 8. $§(1)$ bekezdés.

Ötv. 8. § (4) bekezdés.

Bekényi József (szerk.): Hatásköri jegyzék 2010. Belügyminisztérium, Budapest, 2010.

Ötv. 6. $\S(2)$ bekezdés.

10 Horváth M. Tamás-PÉterı Gábor-VÉcseı Pál: Iskolapélda a pénzügyi decentralizációról. A magyarországi helyi forrásszabályozási rendszer (1990-2012) esete. In: Horváth M. Tamás (szerk.): Külön utak. Dialóg Campus, Budapest-Pécs, 2014, 342. 
terjed, valamint az olyan körzeti jellegü közszolgáltatás megszervezését, ahol a szolgáltatást igénybe vevők többsége nem a szolgáltatást nyújtó intézmény székhelye szerinti települési önkormányzat területén lakik. ${ }^{11}$ Lényegében intézményfenntartói szerepet jelölt ki a rendszer a megyei önkormányzatok számára. Alföldi László a rendszer első éveinek tapasztalatai után úgy fogalmazott, hogy a nem egyértelmü feladatelhatárolás, valamint annak a lehetősége, hogy egyes feladatokat át- vagy épp visszaadjanak, konfliktus forrásává válhat az önkormányzati szintek között. ${ }^{12} \mathrm{Ez}$ a kettősség a rendszer későbbi időszakaiban is érvényesült.

\section{Helyi kiadások funkcionális bontásban az Ötv. alapján ${ }^{13}$}

Ha az Ötv. alapján felvázolt feladatokat szeretnénk rendszerezni, akkor azt értelmezésemben három fö kategória alapján tehetjük meg: így jóléti, illetve humán szolgáltatásokról; gazdasági feladatokról; továbbá tradicionális közigazgatási feladatokról beszélhetünk. Ezek részletezését az 1. számú táblázat tartalmazza. Bár a feladatok súlya nem érzékelhető a felsorolás alapján, elmondható, hogy költségvetési kiadási szempontból (40-50\%-os aránnyal) a legjelentősebb a jóléti, humán szolgáltatások biztosítása volt. ${ }^{14}$

1. táblázat. Helyi közfeladatok (1990-2012)

\begin{tabular}{|l|l|l|}
\hline $\begin{array}{l}\text { Helyi kormányzati } \\
\text { funkció }\end{array}$ & Közfeladat & Szakfeladat \\
\hline $\begin{array}{l}\text { Jóléti, humán } \\
\text { feladatok }\end{array}$ & Oktatás, nevelés & $\begin{array}{l}\text { Elökészítő és alapfokú oktatás, } \\
\text { bölcsőde, óvoda }\end{array}$ \\
\cline { 2 - 3 } & Szociális ellátás & $\begin{array}{l}\text { Szociális otthon, szociális gondozás, } \\
\text { fogyatékosok, hajléktalanok, krízisben lévők } \\
\text { ellátása }\end{array}$ \\
\cline { 2 - 3 } & Egészségügy & $\begin{array}{l}\text { Alapfokú egészségügyi ellátás, } \\
\text { az egészséges életmód közösségi } \\
\text { feltételeinek elösegítése }\end{array}$ \\
\hline
\end{tabular}

11 Ötv. 69. § (1) bekezdés.

12 ALföldı László: Néhány gondolat egy megye szemszögéből a tudományos kutatás és az önkormányzati rendszer kapcsán. In: Csefkó Ferenc-Pálné Kovács Ilona (szerk.): Tények és vélemények a helyi önkormányzatokról. MTA Regionális Kutatások Központja, Pécs, 1993, 221.

13 Az Ötv. 2012. évi legutolsó hatályos teljes változata szerint.

14 HoRvÁTH M. Tamás: A helyi önkormányzatok kapacitáskereteinek ellentmondásossága pénzügyi szempontból. In: Horváth M. Tamás (szerk.): Nézetek és látszatok. KSZK ROP 3.1.1 Programigazgatóság, Budapest, 2006, 23-28. 


\begin{tabular}{|l|l|l|}
\hline $\begin{array}{l}\text { Helyi kormányzati } \\
\text { funkció }\end{array}$ & Közfeladat & Szakfeladat \\
\hline $\begin{array}{l}\text { Gazdasági } \\
\text { feladatok }\end{array}$ & $\begin{array}{l}\text { Szabadidös, kulturá- } \\
\text { lis feladatok }\end{array}$ & $\begin{array}{l}\text { Közmüvelödési, tudományos, müvészeti } \\
\text { tevékenység, sport támogatása }\end{array}$ \\
\cline { 2 - 3 } & $\begin{array}{l}\text { Településüzemelte- } \\
\text { tési feladatok }\end{array}$ & $\begin{array}{l}\text { Ivóvízellátás, csapadék- és szennyvízelve- } \\
\text { zetés, illetve -kezelés, közremüködés } \\
\text { a helyi energiaszolgáltatásban, } \\
\text { helyi közvilágítás, helyi közutak fenntartása, } \\
\text { parkok fenntartása, helyi tömegközlekedés, } \\
\text { tüzoltóság }\end{array}$ \\
\cline { 2 - 3 } & $\begin{array}{l}\text { Környezet- és köz- } \\
\text { egészségügy }\end{array}$ & $\begin{array}{l}\text { Szilárd hulladék gyüjtése } \\
\text { és elhelyezése, temetö üzemeltetése }\end{array}$ \\
\cline { 2 - 3 } & $\begin{array}{l}\text { Településtervezés } \\
\text { és -fejlesztés }\end{array}$ & $\begin{array}{l}\text { Településtervezés, helyi gazdaságfejlesz- } \\
\text { tés, turizmus }\end{array}$ \\
\hline $\begin{array}{l}\text { Tradicionális } \\
\text { közigazgatási } \\
\text { feladatok }\end{array}$ & $\begin{array}{l}\text { Közigazgatás és } \\
\text { helyi rendvédelem }\end{array}$ & $\begin{array}{l}\text { Közigazgatási, hatósági feladatok (hivatal } \\
\text { müködtetése, okmánykiállítás, engedélye- } \\
\text { zés stb.), rendörség, nemzetiségi ügyek }\end{array}$ \\
\hline
\end{tabular}

Forrás: saját szerkesztés az Ötv. alapján

A helyi önkormányzatok kiadásainak vizsgálata több szempontból is elvégezhető. Egyik értelmezésben az egyes települési önkormányzatok egyedi költségvetési kiadási oldalát vizsgálhatnánk, amely megmutatja, hogy adott feladatra pontosan mennyit költött a település. E megoldás alkalmas arra, hogy egy település kiadási szerkezetéről képet kapjunk, de nem alkalmas arra, hogy az egész hazai rendszert reprezentatívan bemutassa. Így kínálkozik egy másik, tágabb megközelítés, mely szerint a nagyobb - közgazdasági szempontú - kategóriák alapján valamennyi önkormányzat összesített költségvetési kiadási adatait elemezzük.

\section{Helyi önkormányzati kiadások közgazdasági bontásban}

A közkiadások nemcsak szakfeladatok szerint csoportosíthatók, hanem közgazdasági szempontból is. E megközelítés a számvitelben használatos föbb mérlegkategóriákra épít, s bár a tartalma részben megegyezik az előző táblázatban feltüntetett feladatokkal, ugyanakkor tágabb is, hiszen itt megjelennek a közfeladatok nyújtásához szükséges beruházások kiadásai is. ${ }^{15}$ Így vizsgálat részét képezik az alábbiak:

- müködési (folyó) kiadások,

- támogatások és egyéb folyó kiadások,

- felhalmozási és tőkejellegü kiadások,

- hiteltörlesztések.

15 Lásd erről részletesen FARKAs Sándorné et al.: Költségvetési szervek kézikönyve I. Költségvetési tervezés, gazdálkodás, beszámolás, ellenőrzés. Saldo, Budapest, 2004, 73-118. 
A müködési kiadások között olyan kiadási tételeket kell értenünk, mint a személyi juttatások, munkaadót terhelő járulékok, dologi kiadások. Így e körbe tartoznak, hogy csak néhány példát említsek, az óvodai dolgozók, a tanárok vagy épp az önkormányzati hivatal alkalmazottainak személyi juttatásai. A dologi kiadások között az önkormányzat által vásárolt készletek, szolgáltatások kiadásai szerepelnek, mint például a villamosenergia-, gáz-, távhő-, ivóvízellátás, szemétszállítás vagy épp a postai levélszállítás. Továbbá idesorolandóak a bérleti díjak, tárgyi eszközök karbantartásának kiadásai vagy épp a kiküldetések, propagandakiadások is. Ez a kör természetesen lehet szűkebb vagy tágabb is, attól függően, hogy az egyes önkormányzatok milyen módon szervezték meg a helyi közszolgáltatásokat, mit láttak el saját költségvetési szerveik útján, és mit bíztak a magánszektorra.

A támogatások és egyéb folyó kiadások kategóriájában olyan kiadások szerepelnek, mint a lakosság (ellátottak) pénzbeli juttatásai, a rendszeres szociális támogatások, lakhatással kapcsolatos támogatások. Továbbá idetartoznak a nemzetközi kötelezettségvállalásból eredő kiadások, a müködési célra kapott, visszatérítendő támogatások, kötelezettségvállalások kiadásai.

A felhalmozási és tőkejellegű kiadások csoportja is igen sokrétü, e körben kell vizsgálnunk a felújítások kiadásait, mint például egy iskola vagy óvoda épületének korszerüsítését, továbbá az intézményi beruházásokat, például egy uszoda, közút vagy közpark építését vagy ingatlanok vásárlását.

A hiteltörlesztés alatt végül mind a belföldi, mind a külföldi hitel-, kölcsöntörlesztés kiadásait értjük, valamint az önkormányzatok által kibocsátott értékpapírok visszavásárlásának kiadásait is.

Természetesen a csoportok bővíthetőek, tovább részletezhetőek, de a helyi költségvetések kiadási oldala föbb jellemzőinek a megállapításához elegendőnek vélem a felsorolt négy kategória alapján történő elemzést, ugyanis a hangsúly a finanszírozási rendszeren van. A tanulmány további részében e kategóriák szerint vizsgálom az 1993 és 2010 közötti időszak helyi költségvetési kiadásait, a Vécsei Pál által idősorosan és településkategóriánként összegyüjtött adatok alapján. ${ }^{16}$

\subsection{Müködési (folyó) kiadások}

A kilencvenes évektől kezdődően a müködési kiadások voltak a legjelentősebbek a költségvetések kiadási oldalán, melyet az 1. számú ábra szemléltet. $E$ körben a legjelentősebb tételek a személyi és bérjellegü kiadások és járulékok, valamint a készletbeszerzés és szolgáltatásvásárlások voltak. Első és legszembetűnőbb megállapítás, hogy a település méretének csökkenésével e kiadási mérték is csökken, azaz általánosságban elmondható, hogy minél kisebb egy település, annál kevesebbet költött. Ha idősorosan vizsgáljuk a diagramot, látható, hogy 1993-tól 1998-ig csökkenés figyelhető meg a müködési kiadásokban, valamennyi településkategó-

16 Vécsei Pál adatbázisának forrásai a Magyar Államkincstártól a VÁTI által évente, dijazás fejében átvett és üzemeltetett TEIR, mely településsorosan tartalmazza az önkormányzatok költségvetési mérlegadatait 1993 és 2010 között. Elérhető az MTA-DE Közszolgáltatási Kutatócsoport adatbankjában. 
ria esetében. A kormányzati ciklusok hatása is érzékelhető, például 1998-tól növekedtek a kiadások, köszönhetően a kormányzati transzferek növekedésének is. 2006-tól viszont újabb csökkenés szemtanúi lehetünk, mely egyrészt a kormányzati megszorító intézkedéseknek, valamint ezt követően a válság hatásának tudható be. Már a rendszer elején látható volt, hogy a müködési kiadások a többihez képest arányában növekednek. László Mária már egy 1993-as tanulmányában megjegyezte, hogy a helyi költségvetésekben egyre inkább a müködési kiadások részaránya nőtt, mely a későbbiekben is meghatározóvá vált. ${ }^{17}$ Megjegyzi továbbá azt is, hogy a források csak a legszükségesebb felújitási, karbantartási munkálatok elvégzésére voltak elegendők, melyek hosszú távon többletköltséget termelnek, másrészt a belső aránytalanságok a települések közötti különbségek növeléséhez vezetnek. ${ }^{18}$ Ez a későbbiekben is igaznak minősült, a rendszer vége felé, ahogy a számok is mutatják, az egy före jutó müködési kiadás a fővárosban körülbelül kétszer akkora volt, mint egy községben.

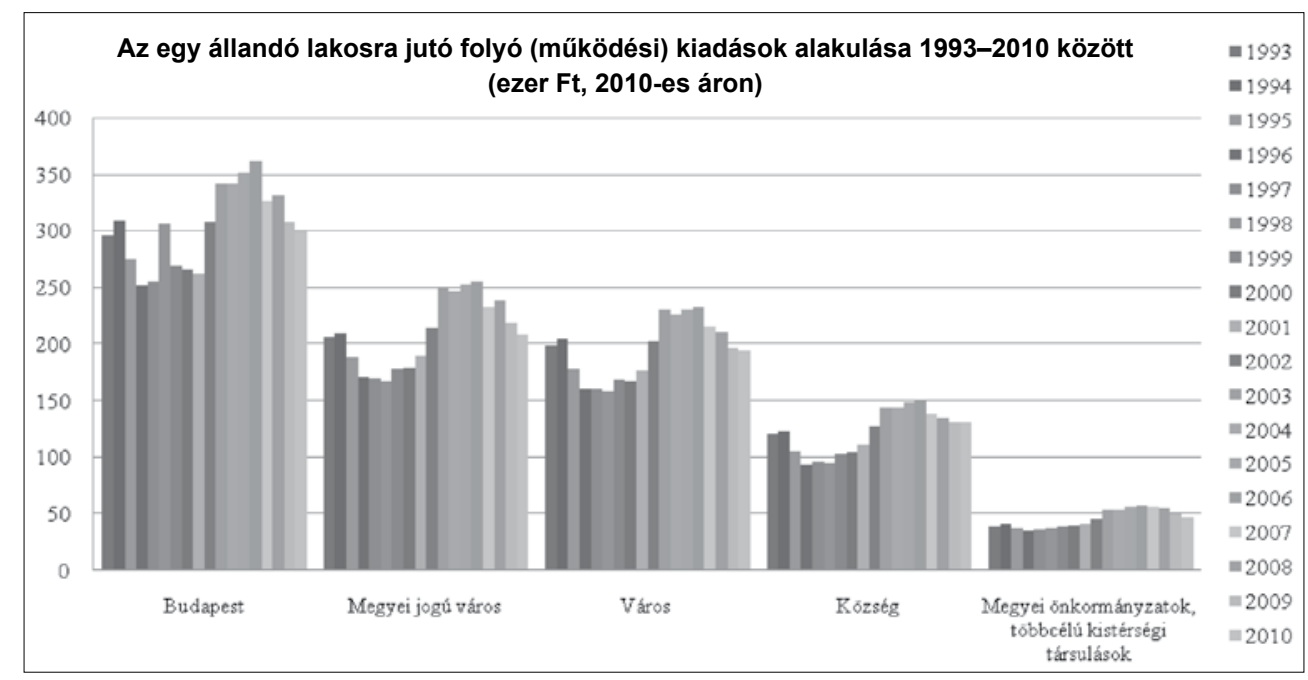

1. ábra. A kiadások alakulása 1993-2010 között

Forrás: saját szerkesztés az MTA-DE Közszolgáltatási Kutatócsoport adatbankja alapján

\subsection{Felhalmozási és tőkejellegü kiadások}

A felhalmozási és tőkejellegủ kiadások a második jelentősebb kiadástípusba sorolhatók, bár összehasonlítva a müködési kiadásokkal, annak nagyjából csak a felét tették ki mindig is. E körben értelmezhetjük az önkormányzatok beruházásokkal,

\footnotetext{
17 LÁszló Mária: Az önkormányzatok feladatai és a finanszírozás. In: Csefkó Ferenc-Pálné Kovács llona (szerk.): Tények és vélemények a helyi önkormányzatokról. MTA Regionális Kutatások Központja, Pécs, 1993, 214.

18 LÁszLó: i. m., 215.
} 
valamint felújításokkal kapcsolatos kiadásait. A településkategóriák között a föváros jelentősen többet tudott e célra fordítani gazdasági, súlyponti szerepéből adódó többletbevételeinek köszönhetően. Érdekes azt is megfigyelni, hogy a városok többet tudtak költeni, mint a megyei jogú városok, egészen 2006-ig, amikor fordult a kocka. Bár az utóbbiak ettől az időszaktól kezdve kerültek az eladósodás pályájára is. A változás nagyban köszönhető a területfejlesztés hazai és uniós forrásai elosztási mechanizmusának. Ha idősorosan vizsgáljuk az adatokat, láthatjuk, hogy egyik évröl a másikra váltakozó mértékben hol csökkentek, hol nőttek a felhalmozási és tőkejellegü kiadások, azaz nem mutatnak állandóságot. Ez alól csak a megyei önkormányzatok voltak kivételek, akik közel azonos szinten tudták fenntartani - a többihez képest csekélynek mondható - felhalmozási jellegü kiadásaikat. A kilencvenes évek közepén és a kétezres évek végén kevesebbet tudtak költeni fejlesztésre vagy épp a meglévő vagyon fenntartására, felújításra. Másrészt a hullámzás tetőpontjai jellemzően a választások évére vagy az azt megelőző évre tehetőek, ugyanis ekkor előszeretettel adtak a kormányok pluszforrásokat fejlesztésre. ${ }^{19}$ Erre a cél- és címzett támogatások köre szolgált, mely a kormányzati döntésnek megfelelő fejlesztések kiadásait finanszírozta. 2006 után itt is érezhető a megszorítások és a válság hatása, jelentősen csökkentek e kiadási tételek. Összességében elmondható, hogy az önkormányzatok nagyban függtek a gazdasági és politikai adottságoktól, változásoktól, de ennek ellenére is tudták alakítani fejlesztési politikájukat. Ezt támasztja alá az is, hogy a müködési kiadásokhoz képest kiegyenlítettebb mértékben jutott pénz fejlesztésekre.

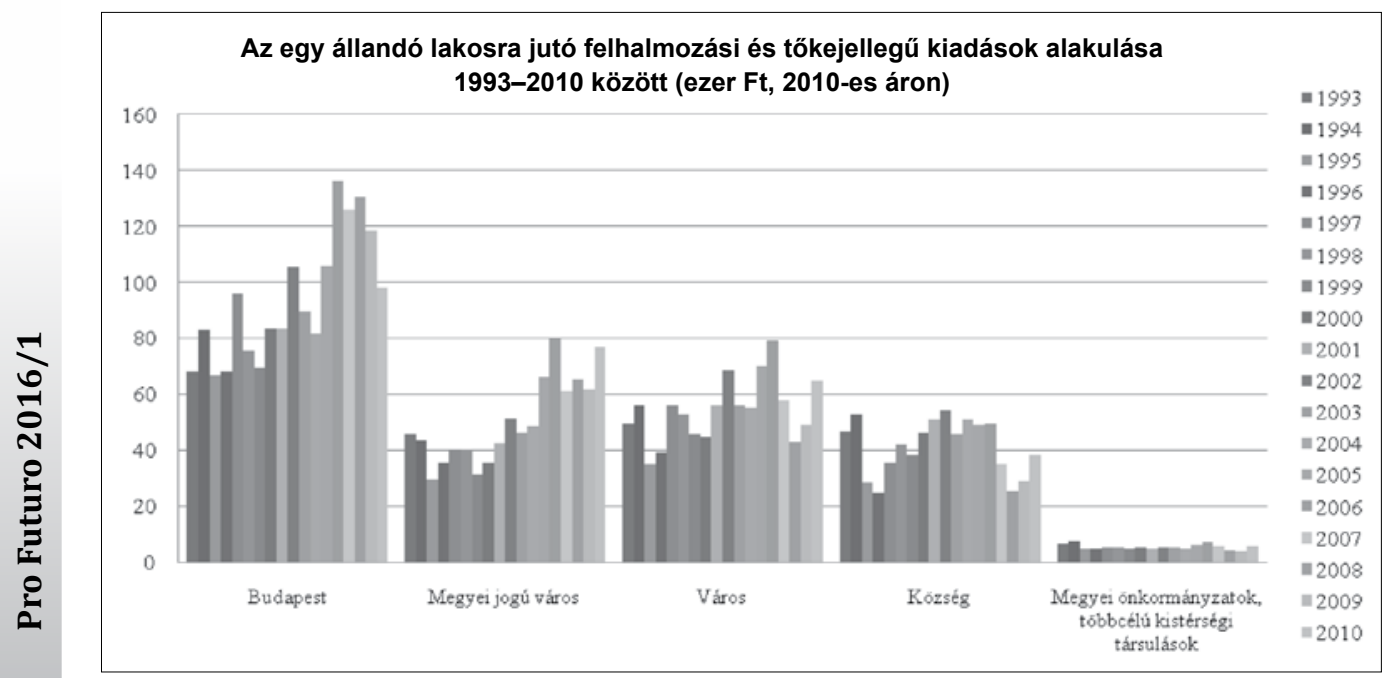

2. ábra. A felhalmozási és tőkejellegű kiadások alakulása 1993-2000 között

Forrás: saját szerkesztés az MTA-DE Közszolgáltatási Kutatócsoport adatbankja alapján

19 Horváth M. Tamás-Péterı Gábor-VÉcseı Pál (2014): i. m., 350. 


\subsection{Támogatások és az egyéb folyó átutalások kiadásai}

A támogatások és egyéb folyó átutalások legnagyobb tételeit rendszerint a lakosok számára nyújtott szociális ellátások, juttatások tették ki. Itt különösen a pénzbeli és nem pénzbeli, föleg rászorultság alapján nyújtott támogatásokra kell gondolni. ${ }^{20}$ A 3. számú ábra adatait megvizsgálva elmondható, hogy a fövárosban volt a legmagasabb e körben a kiadás, föleg az ezredfordulót követően megugró mértékben. Ennek oka a nagyobb népességszámhoz igazodó szociális kiadásokban, valamint a fővárosi tömegközlekedés egyre nagyobb méretű támogatásában keresendő. A többi településkategória esetében igazából nem volt nagy eltérés az egy före jutó kiadási összegekben, minimális mértékben a községekben voltak magasabbak az összegek, ami a hátrányosabb helyzetben lévő, elmaradottabb kistelepülések számlájára írható. Azért sem lehetett jelentős az eltérés, mert a legtöbb szociális ellátás jogszabályi szinten meghatározott mérték alapján volt megállapítható. Jól kivehető az adatokból a megyei önkormányzatok helyzete: mint arra már korábban utaltam, nem láttak el e körben jelentős feladatokat.

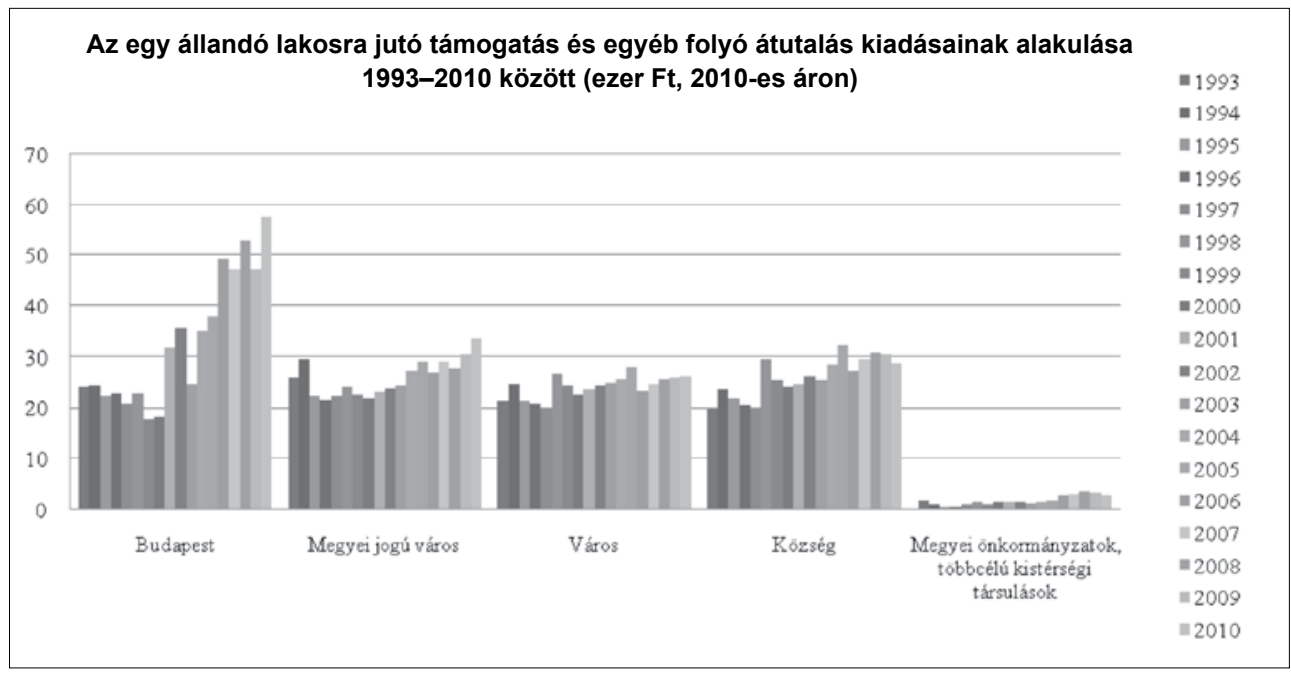

3. ábra. Támogatások és egyéb átutalások 1993-2000 között

Forrás: saját szerkesztés az MTA-DE Közszolgáltatási Kutatócsoport adatbankja alapján

\subsection{Hiteltörlesztések}

A forrásszabályozási rendszer egyik kritikájaként szokták felhozni, hogy nem volt fenntartható, ugyanis nem nyújtott elegendő forrást az egyes feladatok ellátásá-

20 Lásd az Állami Számvevőszék 9913/98. számú jelentését a helyi önkormányzatok által nyújtott pénzbeli szociális ellátások helyzetének vizsgálati tapasztalatairól. 
hoz, ezért a hitelfelvétel valamilyen formájára kényszerültek az önkormányzatok. A hitelfelvételt a költségvetés bevételei között szokás felsorolni, hiszen pénzügyi forrásként jelenik meg. Ugyanakkor a hitel törlesztése a költségvetés kiadási oldalán jelentkezik, így fontosnak tartom itt tárgyalni. A forrásszabályozási rendszerben 2006-ot követően egészen a 2010-es adósságkonszolidációig folyamatosan nőttek a helyi önkormányzati hitelfelvételek, mígnem körülbelül 1200 milliárd forintnyi hitelállományt halmoztak fel. Ez mind a központi adósságállományhoz, mind a GDP-hez viszonyítva elenyészőnek mondható, azt is figyelembe véve, hogy ez az adósság csupán kb. 300 önkormányzatnál összpontosul. Vannak, akik jelentősnek tekintik ezt az összeget, köztük Vigvári András is, aki több kockázatos tényezőre hivatkozva adósságcsapdaként értékeli a kialakult helyzetet. ${ }^{21}$

A 4. számú ábra az egy före jutó hiteltörlesztések kiadásait mutatja. Elsőként megállapítható, hogy a 90-es évek elején sokkal nagyobb mértékben költöttek az önkormányzatok hiteltörlesztésre, mint az azt követő években. 1995-96-ban a legmagasabbak az értékek, aminek az oka, hogy 1996-ig mindenféle jogi korlát nélkül vehettek fel hitelt a helyi önkormányzatok (csupán egy 1996-os jogszabály-módosítással vezették be, hogy a saját bevételek $70 \%$-ánál nem lehet nagyobb a hitelállomány. Ennek hatásaként 1998-ra már jelentősebben csökkentek az összegek. Majd 2007-től figyelhető meg egyfajta általános növekedés a hiteltörlesztések tekintetében, ami egyfelöl az uniós források felhasználásához szükséges önrész biztosítása érdekében, másrészt a válság hatására csökkenő központi támogatás kompenzálására felvett hitelek miatt realizálódott. A településkategóriák között az 1998 elötti és utáni időszakban hasonló változásokat figyelhetünk meg. Azt mondhatjuk, hogy a megyei jogú városokat terhelte leginkább, a főváros és más városok közel azonos szinten voltak, s ehhez képest a községek kisebb arányban költöttek hiteltörlesztésre. Ugyanakkor az 1998 utáni időszakban a kategóriák között kiegyenlítettebb volt a mérték, majdnem azonos mennyiségben szerepelt a költségvetés kiadásai között a hiteltörlesztés. A hitelek szerkezetét tekintve egyébként elmondható, hogy jellemzően fejlesztési hitelekröl volt szó, különösen az utolsó évtizedben az uniós források önrészének biztosítása érdekében, de jelentős volt a müködési célra felvett hitel is, ami a feladatok folyamatos decentralizálásával hozható összefüggésbe. ${ }^{22} \mathrm{~A}$ megyei önkormányzatok és kistérségi társulások a csekélyebb feladatoknak megfelelően kevesebb hitelállománnyal rendelkeztek, így minimális volt a kiadásuk is e körben. Megállapítható tehát, hogy a települések relációjában a legnagyobb arányt képviselő községek költöttek a legkevesebbet hiteltörlesztésre (egy állandó lakosra számítva); megpróbáltak szükös kereteikhez igazodni.

21 SivÁk József-SzEmLÉr Tamás-VıgváRı András: A magyar államháztartás és az Európai Unió közpénzügyei. CompLex, Budapest, 2013, 186-189.

22 VIGVÁRI András: Finanszírozási reform vs. feladatreform. Néhány szempont az önkormányzati rendszer reformjához. Magyar Közigazgatás, 2006/3-4, 232-245. 


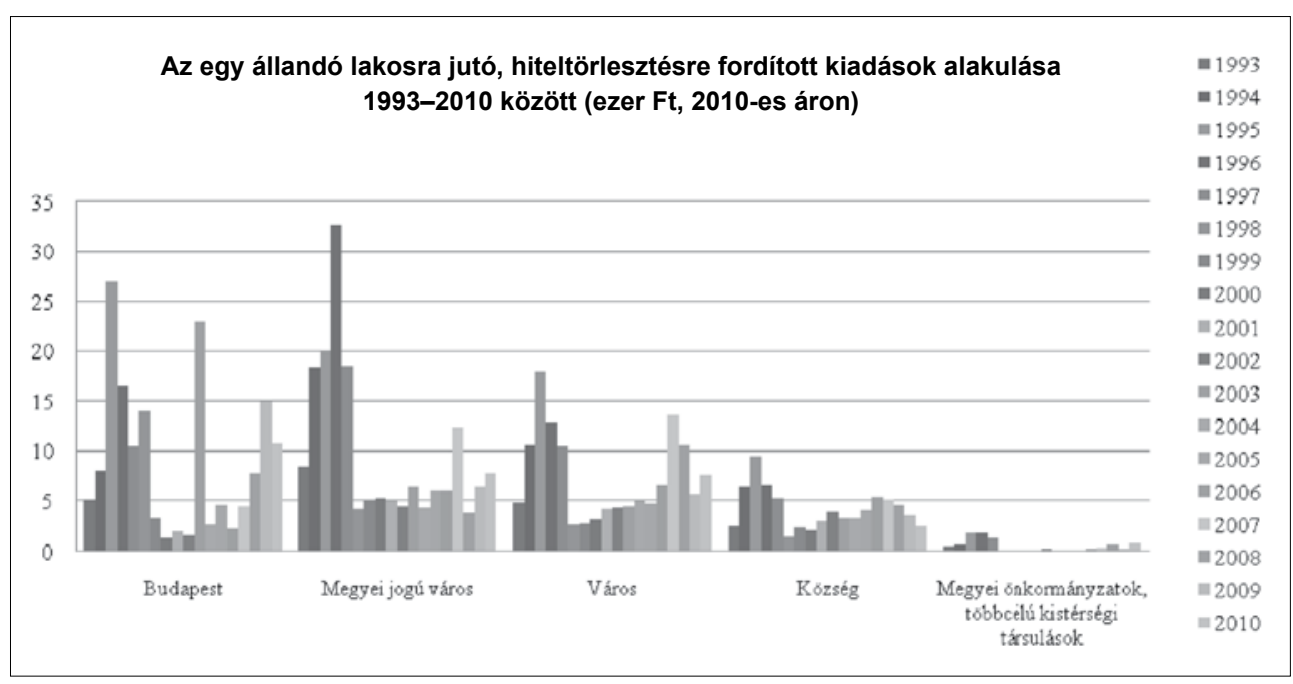

4. ábra. A hiteltörlesztések kiadásai 1993-2000 között

Forrás: saját szerkesztés az MTA-DE Közszolgáltatási Kutatócsoport adatbankja alapján

\subsection{GFS-rendszerü kiadások}

A helyi aggregált kiadások volumenét vizsgálhatjuk a Nemzetközi Valutaalap által kidolgozott kormányzati pénzügyi statisztikai rendszer, azaz a GFS ${ }^{23}$-rendszerben is. Ez a módszer figyelmen kívül hagyja a hitelfelvételböl, értékpapír-kibocsátásból eredő tárgyévi tőketörlesztéseket. ${ }^{24}$ A 4 . ábra adataiból így jól látszik, hogy egy före mennyi kiadás jutott településkategóriánként. Felidézhetjük azt az állítást, amely gyakran előkerült az elmúlt húsz évben - nevezetesen, hogy a kisebb településeken drágább megszervezni egyes szolgáltatásokat, s nem méretgazdaságos. A diagram adataiból azt látjuk viszont, hogy összességében a fővárosban volt a legmagasabb, és a település méretének megfelelően csökkent az egy före vetített kiadás. Természetesen nem mondhatjuk azt, hogy ne lennének eltérések az egyes települések között, de általánosságban igaz lehet az a megállapítás, hogy a közszolgáltatások nyújtása, a közfeladatok ellátása a városban drágább, ami adódhat a közszolgáltatások magasabb fajlagos költségéből, a szolgáltatások esetlegesen jobb minőségéből, de a pazarló gazdálkodásból is. A községben élőkre tehát körülbelül feleanynyi kiadás jutott, mint a fővárosban. A megyei jogú városok és a városok között az eltérés egészen kicsi, a 2002-es évtől valamelyest többet költöttek a megyei jogú városokban. A megyei önkormányzatok szerepét ez a diagram is jól alátámasztja: nemcsak hogy alacsony, de szinte egyenletes is volt a kiadásuk, ami azt is tükrözi,

23 Government Financial Statistics. Az államháztartási mérlegünk 1994-től, a központi költségvetés mérlege 1995-töl ezt a rendszert követi.

24 STIGLITZ, Joseph E.: A kormányzati szektor gazdaságtana. KJK-KERSZÖV, Budapest, 2000, 76. 
hogy a megyei szint esetében nem volt olyan mértékü feladatnövekedés az évek során, mint a települési önkormányzatok esetében.

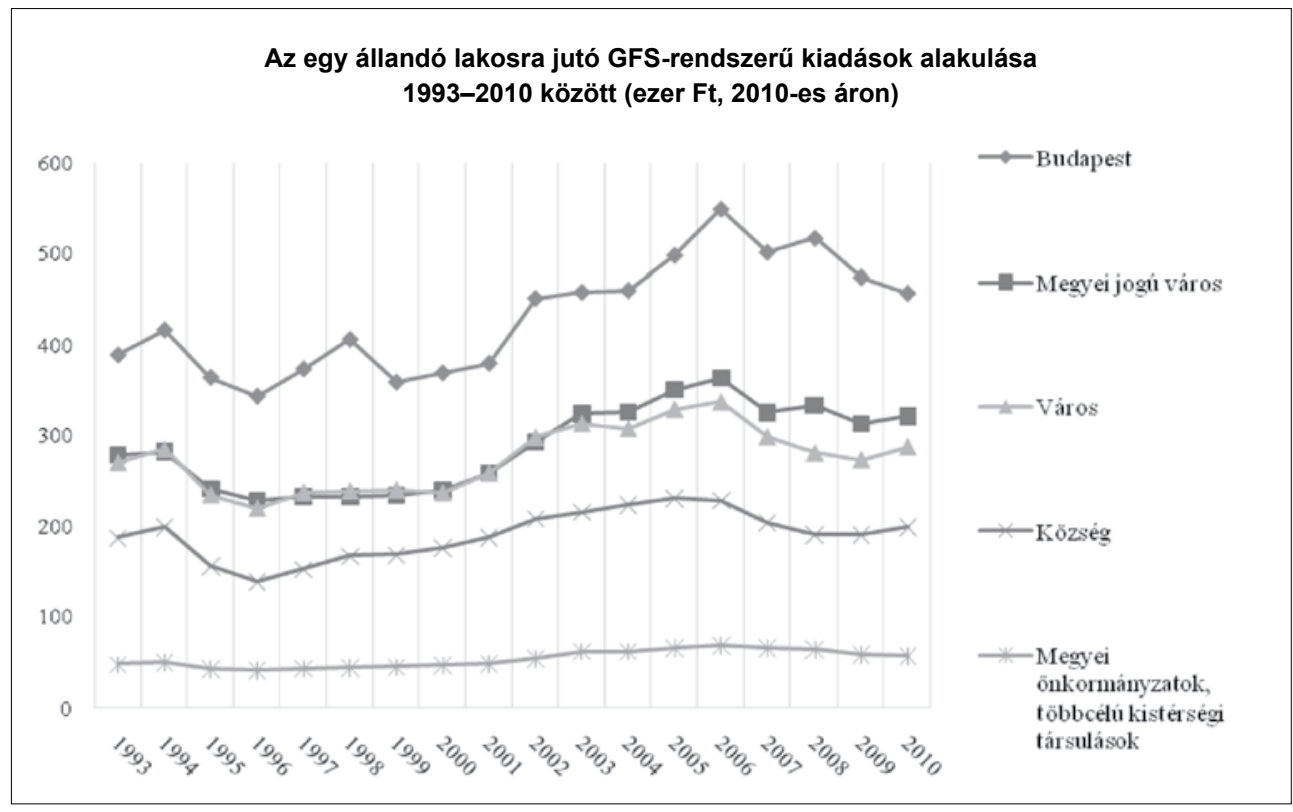

5. ábra. Az aggregált kiadások 1993-2000 között

Forrás: saját szerkesztés az MTA-DE Közszolgáltatási Kutatócsoport adatbankja alapján

\section{Változások 2011-töl}

A helyi önkormányzatok közfeladat-ellátásában jelentős változást hozott a 2011. év jogalkotása, amikor elfogadásra került a Magyarország helyi önkormányzatairól szóló 2011. évi CLXXXIX. törvény (a továbbiakban: Mötv.). De nemcsak az új szabályozás hozott változást, hanem az azóta elindult reformfolyamat, amely alapvetően megváltoztatta a helyi közfeladatok körét és finanszírozását, valamint a helyi pénzügyi autonómia mértékét is, a korábbi rendszerben érvényesülni vélt vagy valós feszültségek okán. ${ }^{25}$ Így célszerủ az elmúlt négy-öt év eseményeit szemügyre venni, és a korábbiakban felvázolt időszak gyakorlatához képest meghatározni a változások irányát. Ugyanakkor fontos azt jelezni, hogy e pár év gyakorlatából még messzemenő következtetéseket nem lehet levonni, csupán a szabályozás újragondolásának föbb aspektusait lehet bemutatni, elemezni.

25 Lásd a korábbi rendszer legfontosabb feszültségvonalait a forrásszabályozási megoldás alapján: HoRVÁTH M. Tamás: Magasfeszültség. Városi szolgáltatások. Dialóg Campus, Budapest-Pécs, 2015, 111-112. 


\subsection{Változások a helyi közfeladatok körében}

A Mötv. helyi közügyekröl és helyben biztosítható közfeladatokról tesz említést, mely utóbbi fogalomhasználat új a rendszerben, s nem tisztázott. Valószínüleg itt olyan feladatokra gondol a jogalkotó, melyek nem helyi közügyek, de nem is kizárólagos államigazgatási feladatok, tehát egyfajta megosztott részfeladatokról beszélhetünk. ${ }^{26}$

A Mötv. feladatrendszerében alapvető változás, hogy differenciált feladat- és hatáskört határoz meg. ${ }^{27}$ Ez válasz lehet a korábbi szabályozásra, mely csak eshetölegesen deklarálta, hogy eltérő feladatai lehetnek az eltérő nagyságú önkormányzatoknak.

A községi önkormányzat köteles ellátni mindazokat a törvényben meghatározott feladatokat, amelyek a helyi lakosság alapvető létfeltételeit, az ehhez szükséges közszolgáltatások közvetlen igénybevételének lehetőségeit biztosítják. A járásszékhely városi, valamint a városi önkormányzat olyan közszolgáltatásokat lát el, melyeket saját területén és vonzáskörzetében vagy a járás egész területén gazdaságosan, hatékonyan és a szakmai elöírásoknak megfelelően képes biztosítani. A megyei jogú város települési önkormányzata - a törvényben meghatározottak szerint, az abban foglalt kivételekkel - azokat a közszolgáltatásokat is biztosítja, melyek saját területén túl a megye egészére vagy nagy részére kiterjednek. ${ }^{28}$ Méretgazdaságossági okokból egyszerübben, költséghatékonyabban szervezhető közfeladat-ellátást kívánt tehát a törvény megteremteni.

E feladatok meghatározásánál négy szempontot ${ }^{29}$ kell különösen figyelembe vennie a jogalkotónak, úgymint a gazdasági teljesítőépességet, a lakosságszámot, a közigazgatási terület nagyságát és a feladat jellegét. Garanciális elemként megjelenik, hogy az ellátáshoz szükséges személyi, tárgyi, szakmai, gazdasági feltételeket is meg kell határozni a feladatot elöíró törvényben. ${ }^{30}$

A feladatátvállalás szabályait is rögzíti a törvény, melynek alapján a nagyobb önkormányzatok számára előirt feladatokat átvállalhatják kisebb önkormányzatok is. Ez arra ad lehetőséget, hogy a kisebb méretú, ugyanakkor nagyobb saját bevételi forrásokkal rendelkező települések saját pénzügyi autonómiájukat kihasználva a helyi közösség igényeinek megfelelöen láthassanak el feladatokat. Ehhez viszont az kell, hogy e feladatokat a lakossági igények indokolják, gazdaságosabban és legalább változatlan szakmai színvonalon lássák el, többlet állami támogatás igénybevétele nélkül.

Továbbra is megmaradt az a lehetőség, hogy az önkormányzat szabadon vállaljon fel közfeladatokat, viszont azzal nem veszélyeztetheti a kötelező feladatok ellátását. ${ }^{31}$ Ezzel próbálja meg a törvény elejét venni annak, hogy egyes önkormányza-

26 Árva-BalÁzs-Balla-Barta-Veszprémi (2012): i. m., 63.

27 Mötv. 11. $\S(1)$ bekezdés.

28 Mötv. 20-21. $\S(2)$ bekezdés.

29 Mötv. 11. $\S(2)$ bekezdés.

30 Az Alaptörvény 34. § (1) bekezdése is kimondja, hogy az elöírt feladattal arányos költségvetési támogatásra jogosultak a helyi önkormányzatok.

31 Mötv. 10. $§(2)$ bekezdés. 
tok nehogy túlvállalják magukat, és veszélyeztessék a költségvetési stabilitásukat. A Mötv. rendelkezik az állami feladatok ellátásáról is. Deklarálásra került, hogy ha állami feladat átadására kerül sor, az csak megállapodás útján, és a szükséges források biztosításával lehetséges. Ez pedig válasz lehet a korábbi időszakban tapasztalt, folyamatos feladatátadásra.

Összességében tehát megváltoztak a feladattelepítés elvei és szabályai, szükebb keretek közé szorítva a helyi közfeladat-ellátást.

A helyi önkormányzati feladatok körét tartalmazza a Mötv., amikor meghatározza, hogy különösen milyen feladatokat kötelező ellátniuk, azzal a kiegészítéssel, hogy a részletszabályokat ágazati törvények adják meg. A felsorolás nem teljes, a Mötv. azt is rögzíti, hogy a helyi közügyek, közfeladatok körében ellátandó további feladatokat törvény is megállapíthat.

Az 1. számú táblázattal összevetve megállapítható, hogy számos feladat kikerült a példálózó felsorolásból, más feladatok pedig rögzítésre kerültek az önkormányzati törvényben. Ezek egy része korábban is helyi feladat volt, csak más jogszabályban került szabályozásra.

2. táblázat. Helyi közfeladatok 2012-töl (a Mötv. alapján)

\begin{tabular}{|c|c|c|}
\hline $\begin{array}{l}\text { Helyi kormány- } \\
\text { zati funkció }\end{array}$ & Közfeladat & Szakfeladat \\
\hline \multirow{3}{*}{$\begin{array}{l}\text { Jóléti, humán } \\
\text { feladatok }\end{array}$} & Oktatás, nevelés & Óvodai ellátás \\
\hline & Szociális ellátás & $\begin{array}{l}\text { Gyermekjóléti szolgáltatások és ellátások, szociális } \\
\text { szolgáltatások és ellátások (települési támogatás ál- } \\
\text { lapítható meg), hajléktalanná vált személyek ellátása } \\
\text { és rehabilitációja }\end{array}$ \\
\hline & Egészségügy & $\begin{array}{l}\text { Egészségügyi alapellátás, az egészséges életmód } \\
\text { elősegítése }\end{array}$ \\
\hline \multirow[t]{4}{*}{$\begin{array}{l}\text { Gazdasági } \\
\text { feladatok }\end{array}$} & $\begin{array}{l}\text { Szabadidős, } \\
\text { kulturális } \\
\text { feladatok }\end{array}$ & $\begin{array}{l}\text { Kulturális szolgáltatások (könyvtári ellátás, filmszín- } \\
\text { ház, előadó-művészeti szervezet támogatása, a kultu- } \\
\text { rális örökség helyi védelme stb.), sport, ifjúsági ügyek }\end{array}$ \\
\hline & $\begin{array}{l}\text { Közművek, } \\
\text { infrastruktúra }\end{array}$ & $\begin{array}{l}\text { Lakás- és helyiséggazdálkodás, helyi környezet- és } \\
\text { természetvédelem, vízgazdálkodás, vízkárelhárí- } \\
\text { tás, hulladékgazdálkodás, távhőszolgáltatás, vízi- } \\
\text { közmü-szolgáltatás }\end{array}$ \\
\hline & $\begin{array}{l}\text { Településüzemel- } \\
\text { tetés }\end{array}$ & $\begin{array}{l}\text { Köztemetők üzemeltetése, közvilágítás, kémény- } \\
\text { seprőipari szolgáltatás, a helyi közutak, közparkok } \\
\text { kialakítása, fenntartása, gépjárművek parkolásá- } \\
\text { nak biztosítása, köztisztaság, települési környezet } \\
\text { tisztaságának biztosítása, rovar- és rágcsálóirtás, } \\
\text { a kistermelök, őstermelők értékesítési lehetőségei- } \\
\text { nek biztosítása }\end{array}$ \\
\hline & $\begin{array}{l}\text { Helyi utak } \\
\text { és közlekedés }\end{array}$ & Helyi közösségi közlekedés biztosítása \\
\hline
\end{tabular}


„Pénzetlen utas nem tud messze menni” - A helyi önkormányzatok költségvetési kiadásai...

\begin{tabular}{|l|l|l|}
\hline $\begin{array}{l}\text { Helyi kormány- } \\
\text { zati funkció }\end{array}$ & Közfeladat & Szakfeladat \\
\hline $\begin{array}{l}\text { Gazdasági } \\
\text { feladatok }\end{array}$ & $\begin{array}{l}\text { Településtervezés } \\
\text { és -fejlesztés }\end{array}$ & $\begin{array}{l}\text { Településfejlesztés, településrendezés, helyi adó- } \\
\text { val, gazdaságszervezéssel és a turizmussal kap- } \\
\text { csolatos feladatok }\end{array}$ \\
\hline $\begin{array}{l}\text { Tradicionális } \\
\text { közigazgatási } \\
\text { feladatok }\end{array}$ & $\begin{array}{l}\text { Közigazgatás és } \\
\text { helyi rendvédelem }\end{array}$ & $\begin{array}{l}\text { Honvédelem, polgári védelem, katasztrófavédelem, } \\
\text { helyi közfoglalkoztatás, helyi közbiztonság, nemze- } \\
\text { tiségi ügyek, átvett államigazgatási ügyek }\end{array}$ \\
\hline
\end{tabular}

Forrás: saját szerkesztés a Mötv. alapján ${ }^{32}$

A feladatok tekintetében a legfontosabb változások egyike, hogy 2012. január 1-jétöl a fövárosi és megyei önkormányzatok fekvőbeteg-ellátása, majd 2012. május 1-jétöl a települési önkormányzatok fekvőbeteg-szakellátása állami feladat lett. A másik nagy változás az volt, hogy 2013. január 1-jétől állami feladattá vált az alapfokú oktatás megszervezése, biztosítása is, az önkormányzatoknál csak az óvodai ellátás maradt. Ezt azért fontos megemlíteni, mert e két feladat tette ki a helyi költségvetésekben a legnagyobb kiadási tételeket. Továbbá a helyi önkormányzatok által ellátott államigazgatási feladatok köre is jelentösen lecsökkent, a kormányhivatali rendszer felállitásával például az okmányügyek, a szabálysértési ügyek, majd 2015 márciusától a pénzbeli és természetbeni szociális ellátások is szintén átadásra kerültek. Ez utóbbival az állam és az önkormányzatok közötti feladatmegosztás a szociális ellátások területén is átalakult.

De nemcsak a közfeladat centralizálására láthatunk példát a táblázat alapján, hanem korábban önkormányzati törvényben nem nevesített feladatok helyi szintre telepítésére is. Ilyen például a helyi közfoglalkoztatás megszervezése; a települési környezet tisztaságának biztosítása, rovar- és rágcsálóirtás; a kistermelők, őstermelők számára értékesítési lehetőségek biztosítása. Bár érdemes azt is megjegyezni, hogy e feladatok nem járnak nagy költségvetési kiadással, föleg, hogy több települési önkormányzat már korábban is látott el hasonló feladatokat.

\subsection{A helyi költségvetési kiadások újabb korlátai}

A feladatszerkezeten túl a helyi költségvetési keretek is újraszabályozásra kerültek, ami a kiadási szintre is hatással van. Lényeges változás, hogy müködési hiány nem tervezhető, ${ }^{33}$ azaz nem lehet negatív eredményủ költségvetési rendeletet elfogadni. Ez a szabály is a fenntartható gazdálkodás, valamint az eladósodás elkerülése érdekében került bevezetésre.

Jól látható, hogy korlátok közé szorítja az önkormányzatok gazdálkodását a jogalkotó, hiszen a Mötv. deklarálja azt is, hogy az önkormányzatok veszteséges gaz-

32 Mötv. 13. $\S(1)$ bekezdés.

33 Mötv. 111. $\S(4)$ bekezdés. 
dálkodásáért a központi költségvetés nem vállal felelősséget. ${ }^{34}$ Vagyis az újonnan képződő hitelállományról van szó, mert mint tudjuk, a rendszer fenntarthatósága érdekében 2011-töl több körben vállalta át az állam az önkormányzatok korábbi hitelállományát. A hitelfelvételt pedig a stabilitási törvény ${ }^{35}$ szabályozta újra, mely a Kormány előzetes jóváhagyását írja fő szabályként elő az önkormányzatok számára, továbbá az adósságot keletkeztető ügyletből származó éves fizetési kötelezettség nem haladhatja meg az adott önkormányzat adott évi saját bevételeinek $50 \%$-át. ${ }^{36}$

Az állami beavatkozás erősödése figyelhető meg a Mötv. 16. $\S$ alapján is, mely szerint, ha az Európai Unió vagy más nemzetközi szervezet felé vállalt kötelezettség határideje eredménytelenül telt el, vagy a határidőben történő teljesítés elmaradásának reális veszélye fennáll, a Kormány a kötelezettséggel összefüggő beruházás megvalósításáról saját hatáskörben gondoskodhat. A helyi önkormányzat köteles a beruházás megvalósításához szükséges, tulajdonát érintő intézkedések türésére. Ami egyfelöl segítség, másfelöl az autonómia csökkentésével járó beavatkozás. A cél ugyanakkor világos: az uniós támogatások kapcsán a minél jobb forrásabszorpció, továbbá a nemzetközi kötelezettségek teljesítésének a biztosítása.

Korábban nem volt közvetlen pénzügyi jogkövetkezménye annak, ha a képviselö-testület nem fogadott el idöre költségvetési rendeletet. ${ }^{37} \mathrm{E}$ téren is változás történt, ugyanis a Mötv. 115. § (2) bekezdése alapján, ha a helyi önkormányzat a költségvetési évre vonatkozóan nem rendelkezik elfogadott költségvetéssel, illetve nem fogadja el a zárszámadást, vagy különféle államháztartási beszámolási kötelezettségeinek nem tesz eleget, akkor a határidő elteltét követő hónaptól a mulasztás megszüntetését követő hónapig a nettó finanszírozás keretében finanszírozott támogatásainak folyósítása felfüggeszthető. Ezáltal motiváltabbá váltak az önkormányzatok, hogy időben fogadják el a szükséges dokumentumokat, teljesítsék beszámolási kötelezettségüket.

\subsection{Változások a helyi költségvetési kiadásokban}

A korábbiakban felsorolt hatásoknak - különösen a feladatmennyiség csökkenésének - köszönhetően jelentősen zsugorodtak a helyi önkormányzati költségvetések, s a központi költségvetési támogatások is. Az alapfokú oktatás és a fekvőbetegellátás generálta korábban az egyik legnagyobb helyi költségvetési kiadási tételt. A változások hatására egyes települések esetében akár a harmadára, felére is viszszaeshetett a helyi költségvetés fö száma. 2012-ig a helyi önkormányzati alrendszer kiadásai a GDP 11-12\%-át tették ki, ami uniós összehasonlításban közepes szintü

Mötv. 112. $\S(2)$ bekezdés.

35 2011. évi CXCIV. törvény Magyarország gazdasági stabilitásáról (a továbbiakban: stabilitási tv.).

${ }^{36}$ Stabilitási tv. 10. § (5) bekezdés.

37 Lásd például 2009 Budapest, Fót; 2010 Szombathely; 2011 Szeged. Ugyanakkor 2010-ben módosításra került - még a korábbi - államháztartásról szóló törvény, melynek alapján, ha nem volt idöre elfogadott költségvetése egy településnek, akkor megnyílt a lehetőség a támogatások felfüggesztésére. 
forrásdecentralizációról árulkodott. ${ }^{38} \mathrm{~A}$ feladatszerkezet és a finanszírozási rendszer átalakítását követően a helyi önkormányzati kiadások a GDP 8,8-9\%-ára estek viszsza, ${ }^{39}$ amivel az alacsonyabb decentralizált forráselosztást megvalósító országok köréhez csatlakoztunk.

2011-töl négy körben sor került az önkormányzati alrendszer adósságkonszolidációjára is, melynek keretében mintegy 1326 milliárd forint adósságot vállalt át az állam. ${ }^{40}$ Ennek hatására a helyi költségvetésekből szinte egészében eltűntek a hiteltörlesztéssel kapcsolatos kiadások. Bár az is igaz, mint korábban utaltunk rá, hogy nem az adósság mértéke, mint inkább összetétele és az eladósodás tendenciája okozta a rendszer problémáját. Hatással van a fentiekre az is, hogy a Mötv. szabályozása értelmében müködési hiány már nem tervezhető a helyi költségvetésbe.

A helyi kiadások közgazdasági bontását tekintve tehát továbbra is megmaradt a müködési és dologi kiadások túlsúlya, bár mértékük a feladatok centralizációjával csökkent. A felhalmozási és tőkejellegủ kiadások nagysága is némiképp csökkent, másrészt a forrásszerkezet átalakult, ugyanis megszüntek a korábbi cél- és címzett támogatások, a normatív támogatások kötött felhasználásúvá váltak. Végül - mint már utaltam rá - megszűnt a korábbi kamatkiadások nagy része is az adósságkonszolidáció révén.

\section{5. Összefoglalás: okok és indokok}

A helyi költségvetések kiadási oldalát elemezve elmondhatjuk, hogy a rendszerváltást követően a müködési költségvetés volt a meghatározó. Épp ezért a felhalmozási és tőkejellegủ kiadásokra kevesebb pénz jutott, ami az önkormányzati vagyonállomány mértékének változásában is látható. ${ }^{41}$ Másrészt az alulfinanszírozottság, valamint az uniós források felhasználása miatt felvett önkormányzati hitelek kényszerpályára állították a helyi költségvetési kiadásokat. A helyi közfeladatok folyamatosan nőttek, ami a költségvetési kiadási oldal adataiban is érzékelhető volt. Az önkormányzati rendszer elaprózottsága, valamint a széles feladat- és hatáskör ellentmondása ún. kapacitásdeficithez vezetett.

Igazolhatjuk azt az állítást is, hogy a nagyvárosi élet közszolgáltatási szempontból drágább, azaz az egy före jutó kiadás a városok esetében volt a legmagasabb, ami a több vagy épp magasabb szintű közszolgáltatások körére utal. A községekben jóval alulmaradtak az egy före jutó kiadások, amit a városi közszolgáltatások elérhetőségével pótolt a rendszer. Érdemes azt is megjegyezni, hogy a városokban ugyan magasabb volt az egy före jutó kiadás, de árnyalja ezt az a jelenség, hogy a városok környékén élök is sok esetben igénybe vettek egyes közszolgáltatásokat (például az általános iskolai oktatást, egészségügyi ellátást), így ha nem csak az állandó

38 Lásd erröl SıVÁk József-VIGVÁRI András: Rendhagyó bevezetés közpénzügyek tanulmányozásába. CompLex, Budapest, 2012, 173, a 9. táblázat összefoglaló adatait.

39 SzENTE Zoltán: Sarkalatos átalakulások - Az önkormányzati rendszer. MTA Law Working Papers, 2014/29, 5.

40 Lentner Csaba: A magyar önkormányzatok adósságkonszolidációja. Pénzügyi Szemle, 2014/3, 330-344.

41 Lásd erről részletesen Vigvári András (szerk.): A családi ezüst. Tanulmányok az önkormányzati vagyongazdálkodás témaköréből. CompLex, Budapest, 2007. 
lakosok körével számolunk, akkor egy alacsonyabb kiadási szint lenne mérhető a városok esetében.

A megyei önkormányzatok szerepe nemcsak a jogszabályban leírtaknak megfelelöen, hanem a kiadási összegeket megvizsgálva is kicsinek mondható, a feladatellátásuk csak szűk körü, intézményfenntartó jellegủ volt.

A kiadási oldal elemzése során láthattuk, hogyan ölt formát helyi szinten az allokáció mint államháztartási funkció. Fontosnak tartom kiemelni, hogy a helyi önkormányzatok kiadási szerkezetét nagyban meghatározta az önkormányzati törvény feladattelepítése, az önként vállalt feladatok köre és az önkormányzat mérete is. Így nemcsak a bevételi struktúrában kell keresni a forrásszabályozás hiányosságát, hanem a kiadási oldal feladatszerkezetét és közgazdasági tagozódását is figyelembe kell venni. Továbbá a szabályozási környezet hatásáról sem feledkezhetünk meg, mely esetében megállapítható, hogy nem volt megfelelő garanciákkal ellátott a korábbi önkormányzati törvény helyi költségvetési gazdálkodásra, hitelfelvételre vonatkozó része.

Összességében a tanulmány elején feltett kérdésre válaszolva elmondható, hogy a kiadási struktúrában a működési kiadások aránytalanul nagy, a tőkejellegű kiadások relatív alacsonyabb volta, valamint a hitelfelvételre, a feladattelepítésre vonatkozó szabályozás hiányosságai voltak a legföbb gyenge pontok. Ez nem volt ösztönző a közfeladatok ellátásának javítására, fejlesztésére, sok esetben csupán a minimális törvényi követelmények biztosítására futotta a keret. Önmagában tehát a forrásszabályozási rendszerről nem állítható, hogy rossz lett volna, de tény, hogy a belső költségvetési arányok és a külső szabályozási környezet nem volt megfelelö.

A 2010-es kormányváltást követően megkezdődött az önkormányzati szektor újraszabályozása is. A Mötv. erősebb garanciális szabályokat vezetett be a helyi költségvetési gazdálkodásban, a hitelfelvételben, jelentösen csökkentette a helyi közfeladatok és közszolgáltatások körét, próbát tett a feladatfinanszírozás bevezetésére, ami a gyakorlatban igazán sohasem valósult meg. Az adósságkonszolidáció révén jelentős pénzügyi tehertöl szabadította meg az önkormányzatokat. Mindezek azt eredményezték, hogy csökkentek a helyi feladatok, a helyi költségvetés kiadásai. De ami ennél fontosabb, hogy véleményem szerint a bevételi struktúra változásával, különösen a központi költségvetési források és a helyi adóbevételek kötött felhasználásúvá tételével együttesen csökkent a helyi autonómia egyik fontos eleme, a pénzügyi önállóság is.

\section{Abstract}

The present study is an analysis of the budgetary expenditures of the Hungarian local governments between 1993 and 2010. One of its main objectives is the presentation of the most significant local public functions. The problem of borrowing and debt management of local governments cannot be ignored in this study. Based on the results of the study it is clear that the operational expenditures were predominant meanwhile the local governments could not dedicate more money to the investment in different domains. The most important failures of the previous system 
were the unfavourable allocation of duties and the decreasing central support. After the adoption of the new Municipal Law, important financial changes put in place. As a tendency of the past few years it can be stated that the scope of local public tasks is narrowing (e.g. the primary education and the social security system were centralized) whilst the budgetary expenditures of local governments are decreasing. As a main conclusion the author states that the local financial autonomy was reduced during the last years. 